\title{
ALTERNATIVE TOURISM IN THE BIOSPHERE RESERVE OF VIZCAINO (REBIVI), MEXICO: FACING THE IMPACTS OF CLIMATE CHANGE
}

\author{
ANTONINA IVANOVA, EKATERINE RAMÍREZ, ANGELICA MONTAÑO \& RODRIGO SERRANO \\ Universidad Autónoma de Baja California Sur, México
}

\begin{abstract}
The Biosphere Reserve of Vizcaino (REBIVI) is the most extensive protected natural area in Mexico. The main economic activities are fishing, aquaculture, alternative tourism, and agriculture. The objectives of the present research are the following: a) Characterize the main alternative tourism activities in the REBIVI, b) Analyze the main impacts of climate change on the alternative tourism in the short and medium term, and c) establish measures of adaptation to these impacts. The methodology applied was: a) research in literature and web pages to locate the main tourism activities in the REBIVI, b) analyze the climate scenarios using GIS geographic information systems, d) determine the main impacts of climate change on the REBIVI, and relate them to alternative tourism activities, c) conduct consultation forums in different locations of the REBIVI to know the perception of the inhabitants on the effects of climate change on tourism resources and d) select adaptation measures and prioritize them, based on multicriteria methodology. The results show the following main threats of climate change: droughts, hurricanes, floods, and sea level rise. The scarcity of water resources can affect the maintenance of pronghorn and bighorn sheep, with relation to water availability and grazing. The recommendation is to carry out water saving programs and build small dams for pluvial water catchment. The hurricanes threaten to be more intense, which would cause change of stream channels that can affect roads and highways. We recommend not building infrastructure near these places. Waters of the Pacific Ocean and the Gulf of California surround the REBIVI, making it vulnerable to sea level rise. The recommendation is to move the infrastructure that is close to the coast and try to build the new tourist infrastructure away from the places prone to flooding. The main resource of attraction for alternative tourism in the REBIVI is the gray whale, for which there is no expected negative impact in general. However, pest's proliferation with the increase in temperature could affect the whales.

Keywords: alternative tourism, protected areas climate change, adaptation, Mexico.
\end{abstract}

\section{INTRODUCTION}

The largest protected natural area in Mexico is the Biosphere Reserve of Vizcaino (REBIVI) with about two and a half million hectares, making up $77 \%$ of the territory of the municipality of Mulege, in the north of the State of Baja California Sur, bordering the state of Baja California and the coastlines of the Gulf of California and the Pacific Ocean. Two of the favorite gray whale (Eschrictus robustus) watching sites in the world are located in the REBIVI: Lagoon Ojo de Liebre and Lagoon San Ignacio.

In this area, there is the largest solar evaporation salt works in Latin America, Exportadora de Sal S.A. of C.V. (ESSA), which produces 7 million tons on average per year. ESSA has been crucial as a trigger for the settlement and economic development of the city of Guerrero Negro [1].

It is worth mentioning that the salinas attract thousands of birds of ecological and tourist interest. The diversity and quantity of birds that arrive in the area have earned for Ojo de Liebre Lagoon the titles of "Site of International Importance of the Hemispheric Shorebird Reserve Network" (WHSRN). As well as Area of Importance for the Conservation of Birds in Mexico (AICA), and has the designation of RAMSAR site together with Laguna San Ignacio [2]. 
The region of the REBIVI contains many other ecological resources that make it a unique region. The presence of the bighorn sheep allows hunting tourism. There are also at least 39 species of fauna, which are in process of or threatened with extinction, being the most important the leatherback, green, hawksbill and loggerhead turtles. Other species are the peninsular pronghorn, the mule deer, the desert fox, the bay seal, the white and brown pelicans, the bald eagles, the royal and the osprey, the peregrine falcon, the quelele, the little burrowing owl, the horned chameleon, the cachora and the crane, among many others [3,4]. There are also 300 species of terrestrial vertebrates as the cougar and wildcat, 26 species of marine mammals such as blue, humpback and gray whales. Additionally, there are around 300 species of invertebrates (10 percent being of great importance in the world market), and 130 species of marine vertebrates (not counting mammals) of which 50 species of fish are important for commercial fisheries, such as tuna, sardine, shark, stingray and marlin (Ibid.).

As if that were not enough, the REBIVI boasts many historical-cultural resources, such as the archaeological remains; cave paintings and petroglyphs dating from the time of the ancient Californios. It also highlights the mission of San Ignacio, the town of Santa Rosalía decreed as state historical monument, fossiliferous deposits, features and geomorphological processes that are of priority scientific interest worldwide [4].

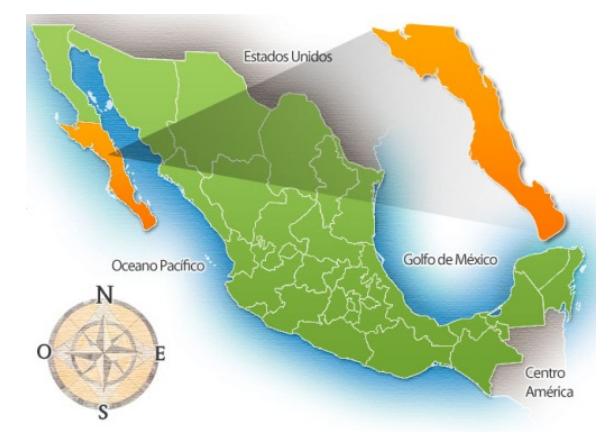

Figure 1: Location of the state of Baja California Sur, Mexico. (Source: www.travelbymexico.com/estados/bajacaliforniasur.)

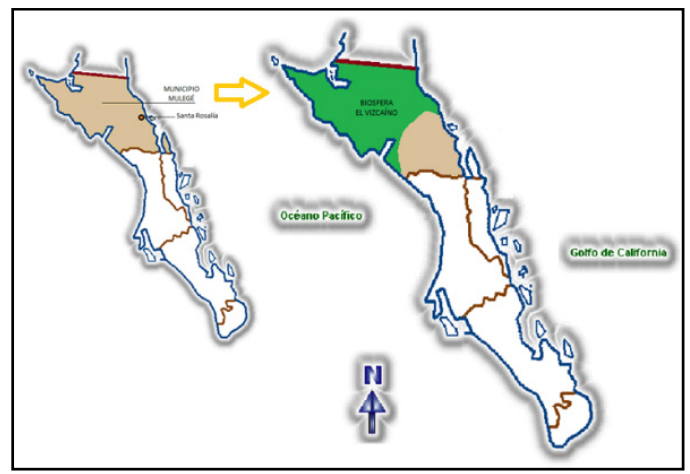

Figure 2: The REBIVI. (Source: [13].) 


\section{THEORETICAL FRAMEWORKS AND METHODOLOGY}

The Fourth Assessment Report of the Intergovernmental Panel on Climate Change (IPCC) states that climate change will affect ecosystems, causing alterations in biodiversity and ecological interactions. This will have a long-term impact on the ecological balance and therefore on the well-being of humanity that is very dependent on ecosystem services. Examples of such alterations are the reduction in abundance of species and the proliferation of invasive species, which influences the following ecosystem services: carbon dioxide capture, fisheries, coastal protection, construction materials, water and food (Ivanova, 2014).

"The State Action Plan for Climate Change for Baja California Sur (PEACC-BCS) recognizes the extreme vulnerability of the entity, derived from its geographical location and specific conditions, with the main real and potential impacts of climate change" [5], [6].

The tourism sector in the state of BCS is very dependent on the global effects of climate change, specifically to sea level rise, floods, rising temperatures, droughts, water scarcity, floods and more extreme cyclones. Those are factors that affect the biodiversity of the REBIVI, increase vulnerability to extreme events, water and food security, and therefore influence the human activities, including tourism [7].

The most alarming aspect in the area in the face of climate change is the availability of water. The aquifers of the municipality present an overexploitation, because it is extracted more water that infiltrates, this coupled with the scarcity of precipitation [4], [5]. In the PEACC-BCS, the recommendation towards this situation is the construction of surface water catchment works and artificial recharge works, since a greater volume of precipitation is expected.

The methodology used was the following:

a) Perform research in literature and web pages to locate the main tourism activities of the REBIVI,

b) Analysis of climate scenarios using GIS geographic information systems,

c) Outline main effects of climate change on the REBIVI, and link them to alternative tourism,

d) Carry out consultation forums in different locations of the REBIVI to know the perception of the inhabitants on the impacts of the tourist resources, and

e) Select and prioritize the adaptation measures according to multicriteria analysis.

Multi-criteria analysis or multi-objective analysis, also abbreviated as AMO, is an instrument that is used to evaluate various possible solutions to a given problem, considering a variable number of criteria, it is used to support decision-making in the selection of the solution more convenient. It is a support tool in the decision-making process, especially in planning, because it allows integrating different criteria according to the intervention of the participants, in a single analysis framework [8], [9].

\section{MAIN ATTRACTIONS FOR DEVELOPMENT OF ALTERNATIVE TOURISM IN THE REBIVI}

The information on the main tourist attractions in the REBIVI is summarized in an infographic (Fig. 3). It is important to highlight that the data collected through bibliographic research were agreed upon seven Community Workshops held in the Reserve: (1) Guerrero Negro, (2) Vizcaíno/San Francisco de la Sierra, (3) La Bocana/Abreojos, (4) San Ignacio/Laguna San Ignacio; (5) Santa Rosalía/Bonfil, (6) Bahía Tortugas/Isla Natividad, (7) Bahía Asunsión. 


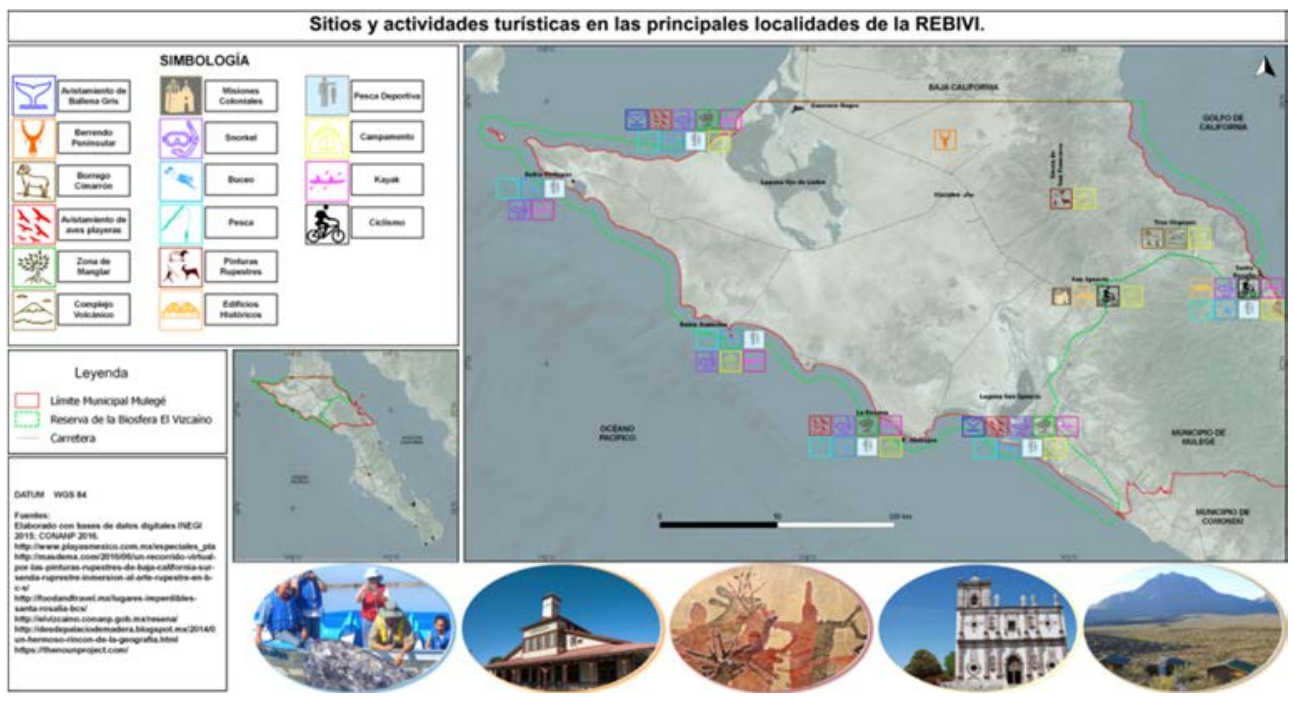

Figure 3: Tourist attractions in the main locations of the REBIVI. (Source: prepared by authors.)

Below we describe the tourist attractions in the main localities of the REBIVI.

\subsection{Santa Rosalía}

From south to north along the trans peninsular highway number 1, the first town with important tourist activity within the Reserve is Santa Rosalía. French buildings and mansions have lasted there since the French mining company El Boleo was established to extract copper at the end of 1800 . This architecture, ruins and monuments are part of the cultural attractions of the town, as is the church that was designed and exhibited by Gustave Eiffel and was the first prefabricated church that was installed in Mexico [10].

Santa Rosalía has the cultural potential and a state of conservation and marginality that makes it have advantages to create strategies based on climate scenarios and sustainable tourism development models, to avoid mass tourism and to design well-managed and sustainable alternative tourism products.

\subsection{Village Ejido Lic. Alfredo V. Bonfil}

73 kilometers from Santa Rosalía following the CT1 to the north, the following area for the tourist practice within the REBIVI is the town: Ejido Lic. Alfredo V. Bonfil. The ejido has many ranch's. In the lands of this ejido is the Volcano of the Three Virgins. Since 1982, Federal Electricity Commission (CFE) established here a geothermal plant, which provides electricity to San Ignacio and Santa Rosalía [10]. This plant is located within a complex of three stratovolcanoes (El Azufre, El Viejo and La Virgen) of the Quaternary geological era [11].

In the area, you can mainly practice the main alternative tourism activities are hunting, camping, hiking, photographic safari, bird and sidereal observation, workshops on regional flora, among others [12]. 
The hunting tourism began with the strategy of promoting conservation and improving the income of the inhabitants of the ejido Bonfil based on sustainable hunting of bighorn sheep; activity that has allowed ejidatarios to work with hunting tourism and ecotourism [13], [14].

\subsection{San Ignacio}

The town of San Ignacio is primordial place for the practice of ecotourism within the reserve. This town also has cultural and scenic attractions, the San Ignacio Lagoon (together with the Lagoon Ojo de Liebre) was declared by UNESCO as a World Natural Heritage. In the lagoon, you can perform gray whale watching, bird watching, kayaking, camping and hiking. The tourism activity of the gray whale sighting is the main activity of the local economy and a great worldwide example of sustainable use of tourism resources [15].

In the lagoon, there are ecotourism cabins, and specialized and authorized guides for whale watching. The company KUYIMA has been innovative and has managed to cope with changes in the patterns of consumption of tourists and take advantage of information technologies. It obtained Green Globe 21 certificate as a company responsible for the environment in whale watching; also, their cabins have G21 certificate for eco lodging.

\subsection{San Francisco de la Sierra}

The next point for the practice of alternative tourism is the community of San Francisco de la Sierra, which is a special place for guided walks, observation of cave paintings and petroglyphs, as well as camping and bird watching.

San Francisco de la Sierra (SFS) is located between San Ignacio and Guerrero Negro, the northernmost mountain range in eastern Baja California [14].

The largest number of sites with rock paintings on Baja California peninsula is located in SFS. SFS is also one of the most important sets of cave paintings in North America. In 1989, the United Nations Organization for Education, Science and Culture (UNESCO) recognized the cultural importance of this site and in 1993, after having complied with the recommendations given by UNESCO; it was named World Heritage Site [16]. The cave paintings are of the "Great Mural" style and are concentrated in 12 spectacular canyons between mountains [17].

\subsection{Punta Abreojos and La Bocana}

Both communities are part of the southwest region of the REBIVI, which in addition to being a fishing area of great importance, mainly fishing for abalone and lobster, is a part of the reserve that houses important species of flora and fauna [18]. This area is habitat of peninsular pronghorn and mule deer. It is part of the migratory route of the gray whale and the blue whale, and a feeding area for sea turtles and refuge for migratory birds, among others [19].

Conservation institutions such as Wildcoast, together with the cooperative Punta Abreojos, currently carry out monthly monitoring to catch, tag and release turtles. This can be beneficial for carrying out turtle release activities, which is undoubtedly a resource that can work for tourism purposes. Other conservation organizations have implemented programs on sustainable use of mangroves [20].

The southwest coastal area and its surroundings have flora and fauna with value for alternative tourism activities: guided hikes, mountain biking, bird watching (Mexican hawk, golden eagle, peregrine falcon)), and a photographic safari of local animals (peninsular pronghorn, mule deer, wildcat, coyote) [4]. 


\subsection{Asuncion Bay}

Asuncion Bay is a coastal community that houses San Ignacio California cooperative, the pioneering cooperative of the North Pacific region and the one that administered the commercial fisheries of the area for many years. Later other cooperatives were founded, such as Bocana and Punta Abreojos [21].

In Asuncion Bay, you can practice sport fishing, surfing, free diving and spearfishing. In addition, the coastal area and surroundings have areas of flora and fauna with value for alternative tourism activities: guided walks, mountain biking, bird watching.

\subsection{Turtle Bay and Punta Eugenia}

Turtle Bay is one of the oldest coastal towns of the North Pacific. The town has maintained a good standard of living, but its fishing boom has diminished [21]. Punta Eugenia is a much smaller community, $15 \mathrm{~km}$ north of Turtle Bay. From this port, you can cross to Natividad Island (there are taxi boats).

This whole area has great potential for alternative sustainable tourism. The alternative tourism activities in these towns are sport fishing, surfing, free diving and spearfishing. In addition, there are activities in the terrestrial part, such as guided hikes, mountain bike and photographic safari of local animals.

\subsection{Guerrero Negro}

Guerrero Negro is a small urban town located near the line that separates the state of Baja California Sur from Baja California State, on the 28th parallel. Lagoons Ojo de Liebre and Guerrero Negro surround this location with an extension of approximately 700 hectares. It had its origin in the foundation of the Exportadora de Sal S.A. of C.V. (ESSA) in 1954. The company constructed houses for its workers that were the pioneer population of the town. Since then, the main economic activity has been the extraction of salt by solar evaporation of seawater. The product is exported mainly to the US market [1], [22].

The other important economic activities are trade, services and fisheries. Regarding the tourism, there are small hotels and restaurants that show top occupancy in the winter season when gray whales arrive in the area [1].

The main tourist attraction of Guerrero Negro and the region is the observation of the gray whale (Eschrictus robustus). These emblematic species of Baja California Sur travel each year 9,000 kilometers from the seas of Bering and Chukchi in the Arctic to the warmest and protected waters in three favorite sites for mating and breeding: Magdalena Bay, San Ignacio Lagoon and Lagoon Ojo de Liebre (the last two within the REBIVI) [23]. This surprising event attracts thousands of tourists a year in the sighting season that lasts from December to March.

It should be noted that the Ojo de Liebre Lagoon (as well as the San Ignacio Lagoon and the cave paintings in the Sierra de San Francisco) was classified in 1993 as a World Heritage site by UNESCO, for being a sanctuary for the gray whale. This global recognition attracts the attention of more tourists, mainly those who seek recreation and education activities in sites with high conservation quality [24].

Another great attraction for tourism (not fully exploited), is bird watching in the Ojo de Liebre Lagoon. The Hemispheric Shorebird Reserve Network declares the location as "Site of hemispheric importance". Recently incorporated alternative tourism activity in Guerrero Negro is the observation of the peninsular pronghorn (Antilocapra Americana). In addition, 
the visit to the ESSA facilities is an interesting experience where you can glimpse the process of salt production. Other products with tourism potential for Guerrero Negro are kayaking and sport fishing [22], [25].

\section{CLIMATE CHANGE ADAPTATION MEASURES FOR ALTERNATIVE TOURISM IN THE REBIVI: RESULTS FROM PARTICIPATIVE COMMUNITY WORKSHOPS (PCW)}

\subsection{Participative Community Workshops dynamics}

This section presents the prioritization processes according to the multicriteria analysis of the adaptation measures of Tourism Strategic Adaptation Axis (SAA) for the REBIVI. First, we present the prioritization criteria used in the 7 Participative Community Workshops (PCW) held in the REBIVI in January-February 2017, and in Abril 2017: 1) Guerrero Negro, (2) Vizcaino/San Francisco de la Sierra, (3) La Bocana/Abreojos, (4) ) San Ignacio/Laguna San Ignacio; (5) Santa Rosalia/Bonfil, (6) Turtle Bay/Isla Natividad, (7) Asunsion Bay.

Subsequently, we explain the methodology implemented at the PCW. The multicriteria analysis is a support tool in the decision-making process and is part of the methodology developed by the German Cooperation for Sustainable Development (GIZ) in conjunction with SEMARNAT to prioritize adaptation measures to climate change [8]. It is used to facilitate the way to the decision, so that different points of view may intervene, even if they may be contradictory. It is a support tool in the decision-making process, especially in planning, because it allows integrating different criteria in a single framework of analysis, according to the intervention of the participants.

Within the process of applying the multicriteria methodology, seven Participative Community Workshops (PCW) were carried out with the objective to gather the observations and comments of the inhabitants of the REBIVI. These served to enrich and further specify the strategies and lines of action of each Strategic Adaptation Axis, both by the society, main stakeholders, and by the agencies that would be responsible for their implementation and follow-up $(7,8)$. In addition, as part of the PCW activities, the participants prioritized the actions of each Strategic Adaption Axis (SAA) based on the multicriteria analysis.

A number of representatives of civil society from the REBIVI participated, including offices of the three levels of government, nongovernmental organizations, community members and producer associations (ranchers, fishermen, farmers), as well as representatives of educational institutions.

Workshop attendees were organized into five working tables, each with facilitator (member of the research team) and a rapporteur. Each table corresponded to the adaptation measures of a strategic sector. The Strategic Adaptation Axes (SAAs) defined in previous meetings of the research team with public officials of the REBIVI and CONANP were the following: Water; Fisheries and Biodiversity; Agriculture and Livestock, Tourism; and Environmental Education and Research. In this paper, we are highlighting only the results related to Tourism SAA. Starting the work of each thematic group, the facilitator presented the work dynamics. After explaining the dynamic issue clearly, participants were asked to write individually each idea or piece of information on a tab. The participants placed their sheets in screens, where the facilitator synthesized the information (eliminating repetitions).

One of the most common techniques used was to encourage discussion and organize ideas into files. The tokens were used in the "brainstorming" and in working with the discussion groups. The discussion took place in two stages: 


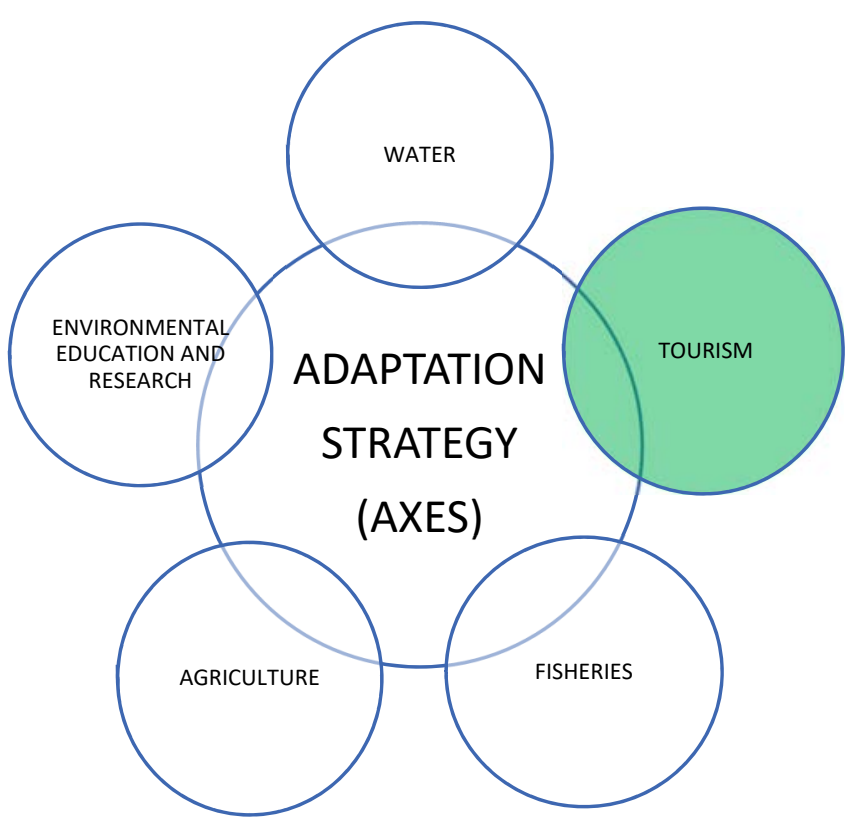

Figure 4: Adaptation Strategy Axes for the REBIVI. (Source: prepared by the authors.)

\subsection{Stage I. Assessment of climate change Impact and identification of adaptation} measures

At this stage the impacts of climate change were identified by the assistants, for example, drought, flooding, sea level rise, etc. Then the level of affectation of each impact was ranked between 0 and 3 ( 0 -no affectation 1 -affects little 2 - affects considerable 3 -affects a lot). Then the consequences of the impact were defined (for example, drought affects crops, sea level rise affects the coastal infrastructure, etc.).

Then the participants defined the most appropriate adaptation strategies according to each impact. Once the adaptation strategies formulated, it was discussed if any support is received for their implementation by governmental institutions or by NGOs (e.g., financing, capacity building, and environmental education).

\subsection{Stage II. Prioritization of adaptation measures identified in the previous stage}

The prioritization was performed according to the multicriteria methodology. The PCW participants discussed the following six criteria, ranking each of them from 0 to 3 :

i. Importance for the community.

ii. Contribution to conservation.

iii. Care for vulnerable population.

iv. Resilience enforcement.

v. Community participation.

vi. Institutional support (government and/or NGOs). 
Then each group of answers was discussed. Subsequently, the ideas were agreed, and possible solutions to the problem were identified.

\subsection{Climate change effects and adaptation measures for tourism in the REBIVI}

The adaptation measures presented here are the result for the Tourism Strategic Adaptation Axis defined during the 7 Participative Community Workshops held in the reserve.

According to the process described, the participants proposed and prioritized measures by multicriteria analysis methodology; Table 1 summarizes the outcomes of the seven PCW.

\section{FINAL REMARKS}

The most appropriate way to counteract the effects of climate change in the REBIVI is through the Ecosystem Approaches for Adaptation, which employs natural resources and the proper management of the environment for climate regulation. In this way, green measures (based on ecosystem services) and gray measures (based on eco technologies) can be used [8].

Table 1: Adaptation measures for tourism in the REBIVI. (Source: Prepared by authors and based on results of the seven Community Workshops held in the REBIVI.)

\begin{tabular}{|c|c|c|c|}
\hline $\begin{array}{l}\text { CLIMATE } \\
\text { CHANGE } \\
\text { EFFECT }\end{array}$ & RANKING & $\begin{array}{l}\text { IMPACT ON } \\
\text { ALTERNATIVE } \\
\text { TOURISM }\end{array}$ & $\begin{array}{l}\text { ADAPTATION } \\
\text { MEASURES }\end{array}$ \\
\hline $\begin{array}{l}\text { Pests } \\
\text { proliferation }\end{array}$ & 3 & $\begin{array}{l}\text { Pests dry vegetation (loss of } \\
\text { landscape) }\end{array}$ & $\begin{array}{l}\text { Large-scale health treatment. } \\
\text { Rescue of affected plants }\end{array}$ \\
\hline $\begin{array}{l}\text { Decrease in } \\
\text { rainfall; } \\
\text { droughts }\end{array}$ & 2.7 & $\begin{array}{l}\text { Loss of flora and landscape } \\
\text { Wildlife mortality }\end{array}$ & $\begin{array}{l}\text { Slotting of deforested areas } \\
\text { for aquifer recharge } \\
\text { Works of channeling of } \\
\text { streams and water retention. } \\
\text { More hydrological-forest } \\
\text { studies to retain water } \\
\text { Reforestation programs. } \\
\text { Cattle management programs } \\
\text { to regenerate soils }\end{array}$ \\
\hline $\begin{array}{l}\text { Torrential } \\
\text { Rains } \\
\text { increase }\end{array}$ & 2.6 & $\begin{array}{l}\text { Increased soil erosion } \\
\text { Deterioration of cultural } \\
\text { heritage (paintings and } \\
\text { missions) } \\
\text { Erosion of accesses, } \\
\text { sidewalks and camping } \\
\text { areas in archaeological, } \\
\text { historical or other tourism } \\
\text { sites. } \\
\text { Floods due to clogging and } \\
\text { poor management of the } \\
\text { basin } \\
\text { Sewage and garbage dumps }\end{array}$ & $\begin{array}{l}\text { Maintenance of sites of } \\
\text { interest } \\
\text { Soil retention strategies } \\
\text { (reforestation) } \\
\text { Water retention works (dams) } \\
\text { Retention works and water } \\
\text { channeling in urban areas } \\
\text { Cleaning causes of streams } \\
\text { and dams } \\
\text { Improvement and planning of } \\
\text { access to sites of interest }\end{array}$ \\
\hline
\end{tabular}


The results show the following main threats of climate change for the REBIVI: droughts, hurricanes, floods, and sea level rise.

As an example of adaptation actions already carried out in the REBIVI related to tourism, there are the conservation of endangered species, the regulations for the sighting of the gray whale, sustainable hunting, reforestation, and the territorial ordering of the reserve.

The main adaptation measures results of the participative community workshops are the following: Large-scale health treatment; rescue of affected marine and terrestrial plants; ranching of deforested areas for aquifer recharge; works of channeling of streams and water retention; reforestation programs. For these measures is crucial the importance of hydrological-forest studies to retain water.

The scarcity of water resources can affect also the maintenance of pronghorn and bighorn sheep, due to water availability and grazing. The recommendation is to carry out water saving programs and build small dams for pluvial water catchment.

The hurricanes threaten to be more intense, which would cause change of stream channels that can affect roads and highways. We recommend not building infrastructure near these places. Waters of the Pacific Ocean and the Gulf of California surround the REBIVI, making it vulnerable to sea level rise. The recommendation is to move the infrastructure that is close to the coast and try to build the new tourist infrastructure away from the places prone to flooding.

The main resource of attraction for alternative tourism in the REBIVI is the gray whale, for which there is no expected negative impact in general. However, pest's proliferation with the increase in temperature could affect the whales.

Undoubtedly, the REBIVI is a special place to promote the endogenous development of the region and the alternative tourism. The capabilities and characteristics of the territory, and expected climate change scenarios must be the basis for decisions on the use of tourism resources. Information technologies, continuous improvement in the institutions, and participation of local communities in decision-making are necessary components to promote economic growth through sustainable tourism in the region, including measures and policies to adapt to the effects of climate change.

\section{REFERENCES}

[1] Castorena Davis, L., Capítulo 5, Una introducción al territorio, la población y la economía de la región Pacífico Norte y de Guerrero Negro, Baja California Sur, en Pedro Noguera Méndez (coord.) Capital social, género y desarrollo, los sistemas productivos pesqueros de la Reserva de la Biosfera El Vizcaíno, México, Universidad de Murcia (España) y Universidad Autónoma de Baja California Sur (México), España, pp. 123-147, 2008.

[2] Hernández, N., Tesis de licenciatura: Análisis socioeconómico y perspectivas del desarrollo del aviturismo en Guerrero Negro, B.C.S. México. UABCS, 2012.

[3] Arizpe C.O., Capítulo VI El ambiente marino, en Sociedad de Historia Natural Niparajá, A.C., Universidad Autónoma de Baja California Sur, Fundación Mexicana para la Educación Ambiental, A.C., Diagnóstico ambiental de Baja California Sur, México, pp. 243-296, 1998.

[4] INE-SEMARNAT, Plan de manejo para la Reserva de la Biosfera El Vizcaíno. Instituto Nacional de Ecología, 2000.

[5] Ivanova, A. \& Gámez, Y.A. (eds). Plan Estatal ante el Cambio Climático para Baja California Sur, 2012, INE-SEMARNAT, CONACYT, Gobierno del estado de Baja California Sur, UABCS. Disponible en línea. http://spyde.bcs.gob.mx/cgds/ files/proyectos/PEACC/foros/Presentacion_Informativa_Foros_PEACC.pdf. 
[6] Ivanova, A., Servicios ecosistémicos y acción climática, opciones para Sudcalifornia. En José Isabel Urciaga García, Desarrollo regional en Baja California Sur, una perspectiva de los servicios ecosistémicos, Universidad Autónoma de Baja California Sur, México, pp. 179-202, 2014.

[7] Ivanova, A., El turismo frente al cambio climático: adaptación y mitigación, en Delgado G., Gay C., Imaz M., y Martínez M., México frente al cambio climático: retos y oportunidades. UNAM, pp. 177-194, 2010.

[8] GIZ \& SEMARNAT, Metodología para la identificación y priorización de medidas de adaptación. México: Componente de Adaptación de la Alianza Mexicana-Alemana de Cambio Climático de la Cooperación Alemana al Desarrollo Sustentable (GIZ), 2013.

[9] Zorrilla, M. \& Kuhlmann, A., Metodología de Priorización Medidas de Adaptación al Cambio Climático. Guía de uso y difusión. México: SEMARNAT y GIZ, 2015.

[10] SECTUR, Destinos de Mulegé: Santa Rosalía, 2016. http://secturbcs.gob.mx/ destinos/mulege/santa-rosalia/.

[11] Ortiz, I. \& Lorenzo, C., Quince años de monitoreo sísmico en el campo geotérmico de Las Tres Vírgenes, BCS. Geotermia, 22(2), pp. 28-34, Julio-Diciembre de 2009.

[12] Maya, R., Recursos geotérmicos para generar electricidad en México. Revista Digital Universitaria, 8(12) ISSN: pp. 1067-6079. Coordinación de Publicaciones Digitales. DGSCA-UNAM. http://www.revista.unam.mx/vol.8/num12/art91/dic_art91.pdf. 2007.

[13] Ramírez Ivanova, E.A., Ecoturismo comunitario como vía de desarrollo local sustentable en áreas naturales protegidas. Caso ejido Benito Juárez, laguna Ojo de Liebre, B.C.S., México, CONANP/EL COLEF/ REBI, 2014,166 pp.

[14] Rodríguez, I. Tesis de licenciatura: Aprovechamiento de los recursos en las áreas naturales protegidas. El caso de San Francisco de la Sierra B.C.S. como oportunidad de potencialidad turística dentro de la Reserva de la Biosfera el Vizcaíno. Universidad Autónoma de Baja California Sur., México, 2016.

[15] Urban, J., Entrevista para el periodico el economista, 2013, http:// eleconomista.com.mx/estados/2013/02/24/laguna-san-ignacio-destino-ballena-grispieza-clave-economia.

[16] Romero, T. \& Varela, J., Diagnóstico para el desarrollo comunitario y conservación de las pinturas rupestres de la Sierra de San Francisco a través del turismo de bajo impacto. Pronatura Noroeste AC, United Nations Foundation. México, p. 802011.

[17] CONANP. Áreas naturales protegidas, 2012. Disponible en www.conanp.gob.mx/regionales/, consultado el 9/01/2017.

[18] INEGI. Indicadores de Baja California Sur en el contexto nacional, 2015.

[19] Arce-Acosta, M., Caracterización y diagnóstico de la región suroeste de la Reserva de la Biosfera el Vizcaíno en el municipio de Mulegé B.C.S., México. UABCS. Tesis, 2012.

[20] WILDCOAST. Acuerdos de destino para protección de manglares: política de conservación estratégica. https://blogcostasalvaje.com/category/manglares/, 2016.

[21] Sanchez, V., "Manejo de áreas naturales protegidas: el caso del Vizcaíno", en Carabia et al., coord., Patrimonio natural de México. Cien casos de éxito, CONABIO Y SEMARNAT, México, pp. 38-41, 2010.

[22] Luna, E., Perspectivas sobre la producción de sal y la economía de la región de Guerrero Negro, B.C.S., ante escenarios de cambio climático. Tesis de maestría. Universidad Autónoma de Baja California Sur, México, 2014. 
[23] Urban, J., Gómez, G., Rojas, L. \& Swartz, S., "Historical changes of gray whales abundante in San Ignacio and Ojo de Liebre breeding lagoons, México." Journal Cetacean Responsible Management, 5, pp. 281-295. 2010,

[24] SEMARNAT-CONANP. Programa de turismo en ANP 2006-2012. México, D.F., 2007.

[25] SECTUR. Visit Baja California Sur, padrón de prestadores de servicios, 201. Disponible en: www.visitbajasur.com, consultado el 9/01/2017. 